\title{
THE CORRELATION BETWEEN LANGUAGE LEARNING STRATEGIES AND PROFICIENCY LEVEL OF ENGLISH DEPARTMENT STUDENTS IN UNIVERSITAS NEGERI MAKASSAR (UNM)
}

\author{
Rismayana \\ Universitas Negeri Makassar \\ rismayanaviory@gmail.com
}

\begin{abstract}
This research was conducted to: (1) identify the frequently language learning strategies used by English department students in UNM, (2) identify proficiency level of English department students in UNM based on TOEFL score, (3) investigate the correlation between language learning strategies and proficiency level of English department students in UNM. The research applied correlational research. The sample of this research was the fourth semester students in academic year 2013/2014. They were from three majors of study program at English department in UNM. Those were English education, English literature and business EnglishThe data were analyzed by using descriptive and inferential statistic through SPSS 21.0 version. The research result showed that (1) metacognitive and social strategies were the most frequently language learning strategies used by the English department students in UNM. This was proven by mean score 3.75 and 3.65 respectively. It was classified as high category of usage, range from 3.5-5.0 score, (2) based on TOEFL score, the proficiency level achieved by the English department students was classified into waystage level (basic user). It was showed by mean score 445.81, range from score interval 337-459, and (3) there was correlation between language learning strategies and proficiency level based on TOEFL score with $\mathrm{F}=2.288$. It showed that the value of $\mathrm{F}_{\text {count }}=2.288$ was greater than $\mathrm{F}_{\text {table }}=2.23\left(\mathrm{~F}_{\text {count }}>\mathrm{F}_{\text {table }}\right)$, or $\mathrm{p}=0.045$ was lower than $\alpha=0.05(p<\alpha)$. Therefore, the result indicated that language learning strategies of English department students had correlation with proficiency level.
\end{abstract}

Keywords: Language learning strategies, proficiency level, correlation

\begin{abstract}
Abstrak
Penelitian ini dilakukan untuk: (1) mengidentifikasi strategi pembelajaran bahasa yang sering digunakan oleh siswa jurusan bahasa Inggris di UNM, (2) mengidentifikasi tingkat kemahiran siswa jurusan bahasa Inggris di UNM berdasarkan skor TOEFL, (3) mengetahui hubungan antara strategi pembelajaran bahasa dan tingkat kemampuan siswa jurusan bahasa Inggris di UNM. Penelitian ini menggunakan penelitian korelasional. Sampel penelitian ini adalah siswa semester 4 tahun akademik 2013/2014. Mereka berasal dari tiga jurusan program studi di jurusan bahasa Inggris di UNM yaitu pendidikan bahasa Inggris, sastra Inggris dan bisnis bahasa Inggris. Sampel terdiri dari 39 siswa dari pendidikan bahasa Inggris, 20 siswa dari literatur Inggris dan 18 siswa dari jurusan bahasa Inggris. Data dikumpulkan melalui kuesioner SILL dan dokumentasi skor TOEFL. Data dianalisis dengan menggunakan statistik deskriptif dan inferensial melalui SPSS versi 21.0. Hasil penelitian menunjukkan bahwa (1) strategi metakognitif dan sosial merupakan strategi pembelajaran bahasa yang paling sering digunakan oleh siswa jurusan bahasa Inggris di UNM. Hal ini dibuktikan dengan skor rata-rata 3,75 dan 3,65. Ini tergolong kategori penggunaan yang tinggi, berkisar antara skor 3,5-5,0, (2) berdasarkan skor TOEFL, tingkat kemahiran yang dicapai oleh siswa jurusan bahasa Inggris dikelompokkan ke dalam tingkat dasar (pengguna dasar). Hal ini ditunjukkan
\end{abstract}


dengan skor rata-rata 445,81, berkisar antara interval skor 337-459, dan (3) terdapat hubungan antara strategi pembelajaran bahasa dan tingkat kemahiran berdasarkan nilai TOEFL dengan $F=2.288$. Ini menunjukkan bahwa nilai Fhitung $=2,288$ lebih besar dari Ftabel $=2,23$ (Fhitung $>$ Ftabel), atau $p=0,045$ lebih rendah dari $\alpha=$ $0,05(p<\alpha)$. Oleh karena itu, hasilnya menunjukkan bahwa strategi pembelajaran bahasa siswa jurusan bahasa Inggris memiliki korelasi dengan tingkat kemahiran. Kata kunci: Strategi pembelajaran bahasa, tingkat kemahiran, korelasi

\section{INTRODUCTION}

There are a number of factors contributing to the success of students in learning a foreign language, particularly in learning English. Those factors are divided in two major factors, namely external and internal factors. The external factors cover some elements, such as teacher, method, media, and learning facilities. Meanwhile, the internal factors involve students' internal factor which consist of age, cognitive, affective and personality. In other words, it can not be denied that students play important and influential role for the success in learning a language.

Starting from an assumption what makes students successful and more effective in learning than others, recently many researchers are interested in conducting researches that focus on investigating students as one of the factors in determining the successful or unsuccessful in learning. In the field of language learning research, learning strategies employed by the students have been seen as notable area. Chamot (2004) highlighted the importance of identifying students' language learning strategies that enable teachers to discover their students' learning strategies prior to teaching. By investigating students' language learning strategies and its relationship with their language proficiency, it may facilitate a greater understanding of their learning problems. Therefore, understanding of language learning strategies can give useful information how to choose the best way in learning a foreign language and also help students to be more independent in learning. So it is very important for teacher/lecturer to introduce language learning strategies that can increase students' proficiency.

\section{LITERATURE REVIEW}

\section{A. The Concept of Language Learning Strategies}

1. Theories of Learning

There are three sets of learning theories as follows:

\section{a. Behaviorism Learning Theories}

Behaviorism equates learning with changes in either the form or frequency of observable performance. Learning is accomplished when a proper response is demonstrated following the presentation of a specific environmental stimulus. Behaviorism focuses on the importance of the consequences of those performances and contends that responses that are followed by reinforcement are more likely to recur in the future. The learner is characterized as being reactive to conditions in the environment as opposed to taking an active role in discovering the environment (Ertmer and Newby, 1993).

$b$. Cognitive Learning Theories 
Cognitive theories stress the acquisition of knowledge and internal mental structures and, as such, are closer to the rationalist end of the epistemology continuum (Bower \& Hilgard, 1981). Learning is equated with discrete changes between states of knowledge rather than with changes in the probability of response.

\section{c. Constructivism}

Constructivism is a theory that equates learning with creating meaning from experience (Bednar et al., 1991). Even though constructivism is considered to be a branch of cognitivism (both conceive of learning as a mental activity), it distinguishes itself from traditional cognitive theories in a number of ways. Most cognitive psychologists think of the mind as a reference tool to the real world; constructivists believe that the mind filters input from the world to produce its own unique reality (Jonassen, 1991).

\section{Information Processing in Learning}

According to Atkinson and Shiffrin (1968), the stage theory information process model recognizes three types or stages of memory: sensory memory, shortterm or working memory, and long-term memory. Those stages are represented in the figure below.

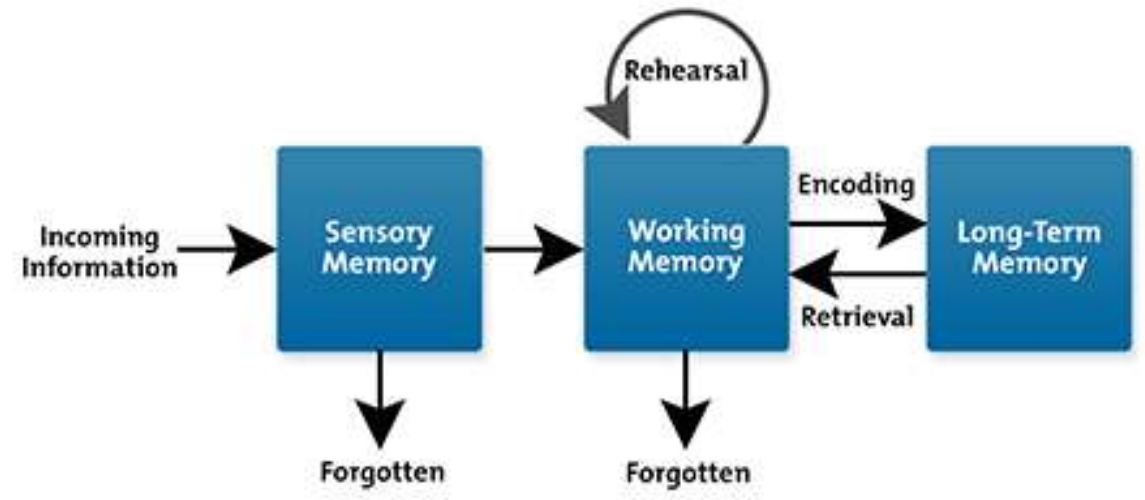

Figure 1: Information Processing Model of Human Learning.

\section{The Definition of Language Learning Strategies}

"Strategy" comes from the ancient Greek term strategia refers to generalship or the art of war. It involves the optional management of troops, ships, or aircraft in a plan battle. The basic characteristics of strategy imply planning, competition, conscious manipulation and movement toward a goal. Gradually, the concept of strategies has become influential in education (Oxford, 1990: 7-8). Furthermore, Oxford (1990) defined learning strategies as specific actions taken by the learner to make learning faster, more enjoyable, more effective, and more transferrable to new situations.

\section{Factor Affecting Choosing Language Learning Strategies}


According to Gavriilidou and Psaltou-Joycey (2009), there are some factors that can affect learning strategies choice. They are as follows:
a. Proficiency level
$f$. Field of study/career orientation
b. Age
g. Culture
c. Gender
h. Beliefs
d. Motivation
i. Task requirements
e. Learning style
j. Language teaching method

5. Oxford's Classification of Language Learning Strategies

There are six major groups of second language learning strategies that have been identified by Oxford. According to oxford (1990), second language learning strategies consists of two major categories as follows:

\section{a. Direct Strategies}

Direct strategies are defined as "strategies involving mental process and directly influencing the target language," (Oxford 1990: 14). Direct strategies is composed of memory strategies for remembering and retrieving new information, cognitive strategies for understanding and producing the language, and compensation strategies for using the language despite knowledge gaps.

b. Indirect Strategies

Indirect strategies are those supporting and managing language without directly involving the target language. Indirect strategies consist of metacognitive strategies, affective strategies, and social strategies.

6. Method for Identifying Language Learning Strategies

According to Gavriilidou and Psaltou-Joycey (2009), there are four ways for identification learning strategies choice. The four ways are:
a. Interview
b. Diaries and Journals
c. Think-aloud Protocols
d. Questionnaires

\section{B. The Concept of Proficiency}

1. Definition of Language Proficiency

Briere cited in Farhady (2010) states that the term 'proficiency' may be defined as the degree of competence or the capability in a given language demonstrated by an individual at a given point in time independent of a specific textbook, chapter in the hook, or pedagogical method. Clark cited in Farhady (2010) defines language proficiency as the language learner's ability to use language for reallife purposes without regard to the manner in which that competence was acquired.

2. Measuring Language Proficiency

The TOEFL test is an internationally accepted standard of English that measures the academic English proficiency of a non-native speaker of English. The TOEFL test is available in two ways as follows: 
a. International Testing Program is divided into TOEFL CBT (computer-based or IBT) and TOEFL P\&P (paper based).

b. Institutional Testing Program, there are two types of institutional testing program; they are Pre TOEFL (paper based) and TOEFL ITP (paper based).

\section{RESEARCH METHODOLOGY}

\section{A. Population and Sample}

The population of the research was English department students in UNM academic year 2013/2014. They were the fourth semester English department students They were 158 students of English education, 68 students of English literature and 115 students of Business English. The total of population was 341 students.

This research applied stratified random sampling. Stratification is used when the population reflects imbalance on characteristic of a sample. In this research the researcher divided the sample into three groups represented three majors in English department.

\section{B. Instruments}

In this research, the researcher utilized two instruments. They were questionnaire and TOEFL score. SILL (Strategy Inventory for Language Learning) questionnaire was used to get data about students' language learning strategies. The researcher distributed SILL to identify language learning strategies of the students. The second instrument was TOEFL score. The TOEFL score was used to get information about students' language proficiency level.

\section{Data Collection}

The students were given TOEFL test by CLS. The time allotted to answer the test was 115 minutes. The students of English education were the first respondents that were tested on July $5^{\text {th }}$, 2014, followed by English literature on July $12^{\text {th }}$, 2014, and business English on July 19 ${ }^{\text {th }}, 2014$. Then, the researcher took the TOEFL score of the students after distributing the questionnaire. It was collected from CLS. The last step, the researcher gave questionnaire to students after TOEFL test took place. The time allotted to answer the questionnaire was 20 minutes. The questionnaire was completed by the students and the researcher analyzed and interpreted it.

\section{Data Analysis}

1. The SILL Result Analysis

a. After collecting the data from questionnaire, the students' results were tabulated in the table 3.4.

Table 3.4 Students' SILL Result

\begin{tabular}{|c|c|c|c|c|c|c|}
\hline Part A & Part B & Part C & Part D & Part E & Part F & Whole SILL \\
\hline & & & & $1 . \ldots \ldots$ & & SUM Part A \\
\hline ..... & & & & 2. & & SUM Part B \\
\hline 3..... & 3. .... & $3 . \ldots \ldots$ & 3..... & 3. .... & 3..... & SUM Part C \\
\hline Etc. & Etc. & Etc. & Etc. & Etc. & Etc. & Etc. \\
\hline SUM & SUM & SUM & SUM & SUM & SUM & SUM \\
\hline$\ldots$ & $\ldots$ & $\ldots$ & $\ldots$ & .... & & \\
\hline
\end{tabular}




$$
\div 9=\_|\div 14=| \div 6=\_\left|\div 9=\_\right| \div 6=\_\left|\div 6=\_\right| \begin{aligned}
& \div 50= \\
& \begin{array}{l}
\text { (Overall } \\
\text { Average) }
\end{array}
\end{aligned}
$$

b. After being identified, the averages of the students' SILL score were interpreted into three categories; they were low category use, moderate category use, and high category use.

Table 3.5 Category of Strategies Use

\begin{tabular}{|l|l|c|}
\hline Category & \multicolumn{1}{|c|}{ Statement } & Score \\
\hline \multirow{2}{*}{ High } & Always or almost always used & 4.5 to 5.0 \\
\cline { 2 - 3 } & Usually used & 3.5 to 4.4 \\
\hline Moderate & Sometimes used & 2.5 to 3.4 \\
\hline \multirow{2}{*}{ Low } & Generally not used & 1.5 to 2.4 \\
\cline { 2 - 3 } & Never or never almost used & 1.0 to 1.4 \\
\hline
\end{tabular}

\section{Correlational Analysis}

After collecting the data from analysis of questionnaire and ELTIC score, the data was analyzed by using statistical package for the social sciences (SPSS 21). Descriptive statistics, such as frequencies, means and standard deviation was used to investigate the most frequently language learning strategy used by the fourth semester English department students in UNM. Then, the researcher also used inferential statistics. The researcher applied multiple regression test. According to Gay et al. (2006:369), multiple regression equation uses variables that are known to predict (correlate with) the criterion variables. In order to identify the degree of correlation, the interpretation of correlation coefficient is presented in the table 3.6 as follows:

Table 3.6 The Interpretation of Correlation Coefficient

\begin{tabular}{|c|c|}
\hline Coefficient interval & Degree of correlation \\
\hline $0.00-0.199$ & Very Low \\
\hline $0.20-0.399$ & Low \\
\hline $0.40-0.599$ & Moderate \\
\hline $0.60-0.799$ & High \\
\hline $0.80-1.000$ & Very High \\
\hline
\end{tabular}

(Sugiyono: 2007) 


\section{FINDINGS AND DISCUSSION}

\section{The Students' Language Learning Strategies}

The findings of the research deal with research questions which were collected through questionnaire and TOEFL score. Language learning strategies consist of six categories. Those are memory, cognitive, compensation, metacognitive, affective, and social strategies. There are three majors of study that are elaborated, namely English education, English literature and business English. The data obtained from the SILL questionnaire were analyzed by using descriptive statistics with SPSS 20 version for windows. The research results are presented as follows The table 1 shows the mean, standard deviation (SD), degree, rank of language learning strategies.

Table 1. Mean Score,Standard Deviation and Rank of Language Learning Strategies English Education, English Literature and Business English

\begin{tabular}{|c|c|c|c|c|c|c|c|c|c|}
\hline \multirow{2}{*}{ Strategies } & \multicolumn{3}{|c|}{ English Education } & \multicolumn{2}{c|}{ English Literature } & \multicolumn{2}{c|}{ Business English } \\
\cline { 2 - 11 } & Mean & SD & Rank & Mean & SD & Rank & Mean & SD & Rank \\
\hline Memory & 3.27 & .59 & 3 & 3.25 & .50 & 5 & 3.17 & .56 & 4 \\
\hline Cognitive & 3.25 & .60 & 4 & 3.21 & .61 & 6 & 3.25 & .60 & 3 \\
\hline Compensation & 3.16 & .58 & 6 & 3.34 & .79 & 3 & 3.01 & .82 & 6 \\
\hline Metacognitive & 3.78 & .66 & 1 & 3.67 & .75 & 2 & 3.80 & .70 & 1 \\
\hline Affective & 3.18 & .76 & 5 & 3.25 & .67 & 4 & 3.14 & .53 & 5 \\
\hline Social & 3.54 & .72 & 2 & 3.91 & .71 & 1 & 3.62 & .74 & 2 \\
\hline Total Score & 3.36 & .47 & & 3.41 & .41 & & 3.34 & .49 & \\
\hline A & & & & & & & & \\
\hline
\end{tabular}

As shown in table 1 th the mean score of English Education $(\mathrm{M}=3.78)$ and English Bussiness students $(\mathrm{M}=3.80)$ indicated that metacognitive strategies as the high frequently used strategies while for English Literature students hey prefer social strategies as the high frequenstly strategies used(M=3.91). Furthermore the table 1 revealed that the least frequently used strategy was different .The lowest mean score for English Education $(M=3.16)$ and Business English Students $(M=3.01)$ showed that the strategies ranked as lowest is compensation strategies with mean score .Moreover for English Literature students, cognitive strategies $(M=3.21)$ is the least frequent strategies that were used by the English Literature students.

In this research, it can be concluded that the metacognitive and social strategies were the most frequently strategies that were used by the English department students in UNM with high frequency of usage .Meanwhile, compensation strategies was the least frequently used strategies that was used in medium frequency of usage. None of the six strategies placed in low frequency of usage. This study produced similar results to previous related finding of the language learning studies, especially in Indonesian context which was conducted by Weda (2005) who found that social strategies and metacogntive strategies were the most frequently used 
strategies, and compensation strategies was the least frequently used strategies. Moreover, the researcher was consistent with the previously studies (e.g Radwan,2011; Salahshour et al. ,2012) which reported that metacognitive and social strategies were the most frequently used strategies, meanwhile compensation and affective strategies were the least frequently used strategies. However, the result of this research where social strategies as one of the highest frequently used strategies did not match with the findings of Chamot (2004) who reported that Asian second language learners tended to use more rote learning and language rules and less communicative strategies. Furthermore, the result of this current research was not fitted to some former results found by Ling-Wu (2008) and Yilmaz (2010). They reported that compensation strategies were mostly frequently used strategies. These previous results were inconsistent with this current research where the compensation strategies were the least frequently used strategies.

\section{The Students' Proficiency Level}

The data collected from the result of TOEFL score by English department students from three majors of study program is presented in table 2 . It is showed the mean score and standard deviation (SD).

Tabel .2 Proficiency Level of English Education, English Literature and Business English Students

\begin{tabular}{|l|c|c|c|c|c|c|c|c|}
\hline \multirow{2}{*}{ Level } & \multicolumn{2}{|c|}{ Eng.Education } & \multicolumn{2}{c|}{ Eng.Literature } & \multicolumn{2}{c|}{ Buss.English } & \multicolumn{2}{c|}{ Total } \\
\cline { 2 - 9 } & F & \% & F & \% & F & \% & F & $\%$ \\
\hline $\begin{array}{l}\text { Effective } \\
\text { Operational } \\
\begin{array}{l}\text { Proficiency } \\
\text { (Proficient User) }\end{array}\end{array}$ & 0 & 0 & 0 & 0 & 0 & 0 & 0 & 0 \\
\hline $\begin{array}{l}\text { Vantage } \\
\text { (Independent } \\
\text { User) }\end{array}$ & 3 & 7.69 & 0 & 0 & 0 & 0 & 3 & 3.90 \\
\hline $\begin{array}{l}\text { Threshold } \\
\text { (Independent } \\
\text { User) }\end{array}$ & 17 & 43.59 & 8 & 40 & 4 & 22.22 & 29 & 37.66 \\
\hline $\begin{array}{l}\text { Waystage } \\
\text { (Basic User) }\end{array}$ & 19 & 48.72 & 12 & 60 & 14 & 77.78 & 45 & 58.44 \\
\hline Total & 39 & 100 & 20 & 100 & 18 & 100 & 77 & 100 \\
\hline
\end{tabular}


As shown in table 4.28, from the total sample of three majors of study program, there was no student who got score in two highest level based on ETS classification score namely Effective Operational Proficiency and Vantage Level. In the next level, there were only 3 students who were in vantage level or they can be classified as independent users. Those were from English education students whereas from two other majors there was no student who can achieve score in the vantage level. Next, in threshold level, there were 29 students (37.66\%) who got score in this level. It consisted of 17 students from English education, 8 students from English literature and 4 students from business English. In the waystage level, more than half of the total sample or 45 students $(58.44 \%)$ can achieved score in this level .They can be classified as Basic Users. There were 19 students from English education, 12 students from English literature, and 14 students from business English .It indicated that most of English department students in UNM were in the waystage level of proficiency based on score obtained in TOEFL.

\section{The Correlation between Language Learning Strategies and Proficiency Level}

The researcher used inferential statistic to investigate the correlation between students' language learning strategies and proficiency level. Its result proved the hypothesis of the research. The result of correlation between two variables can be seen in the tables:

The correlation analysis using IBM SPSS version 21.0 of English Department students showed in the table 3 and 4 .

Tabel 3 .ANOVA

\begin{tabular}{|ll|r|r|r|r|r|}
\hline Model & & Sum of Squares & Df & Mean Square & F & Sig. \\
\hline \multirow{3}{*}{1} & Regression & 28546,941 & 6 & 4757,823 & $\mathbf{2 , 2 8 8}$ & $\mathbf{, 0 4 5}^{\mathbf{b}}$ \\
& Residual & 145575,137 & 70 & 2079,645 & & \\
\\
\cline { 2 - 6 } & Total & 174122,078 & 76 & & & \\
\hline
\end{tabular}

a. Dependent Variable: Proficiency

b.Predictors: (Constant), Social, Compensation, Memory, Metacognitive, Affective, Cognitive

The researcher compared the value of $\mathrm{F}_{\text {count }}$ and $\mathrm{F}$ table, or probability values and $\alpha=$ 0.05. It refers to the interpretation if $F_{\text {count }}>F_{\text {table }}$ or $p<\alpha$, it can be concluded that there is correlation. Meanwhile, if $\mathrm{F}_{\text {count }}<\mathrm{F}_{\text {table }}$ or $\mathrm{p}>\alpha$, it means that there is no correlation or relationship or those six language learning strategies simultaneously correlated to proficiency level. From the result of data analysis, it showed that the value of $F_{\text {count }}=2.29$ was greater than $F_{\text {table }}=2.23\left(F_{\text {count }}>F_{\text {table }}\right)$, or $p=0.045$ was lower than $\alpha=0.05(p<\alpha)$. Therefore, the result indicated that the null hypothesis $\left(\mathrm{H}_{0}\right)$ was rejected or it can be concluded that hypothesis $\left(\mathrm{H}_{1}\right)$ was accepted.

Tabel 4. Model Summary

\begin{tabular}{|l|r|r|r|r|r|}
\hline Model & R & R Square & \multicolumn{1}{|c|}{$\begin{array}{c}\text { Adjusted R } \\
\text { Square }\end{array}$} & $\begin{array}{c}\text { Std. Error of the } \\
\text { Estimate }\end{array}$ & Durbin-Watson \\
\hline 1 & $\mathbf{4 0 5}^{\mathbf{a}}$ &, 164 &, 092 & 45.60312 &, 887 \\
\hline
\end{tabular}


Based on the result in the table above, it revealed $\mathrm{R}=0.405$. It can be interpreted that degree of correlation between language learning strategies and proficiency level was in moderate level. The Anova result in Table 3 showed the simultaneous correlation between language learning strategies as predictor variable and proficiency level as criterion variable. Meanwhile coefficient result revealed the partial correlation of each language learning strategy and proficiency level.

In Indonesian context, the result of this research was contradictory to the result findings of the research which was conducted by Maulina (2013). She reported that there was not significant correlation between language learning strategies used by both successful and unsuccessful male and female students and their English achievement.

On the other hand, this current research had similar result with the others which were found by Griffiths (2003), Ling-Wu (2008) Mohammadi (2009), and Chi and Tam (2013). These researches found that there is a positive correlation between language learning strategies and proficiency. Therefore, it can be considered that the students' English proficiency level was influenced by other factors that might come from students' factors such as language learning strategies applied by the students whether inside or outside of the classroom. Regarding to result of proficiency test, this research revealed that compensation strategies had partial correlation with the students' proficiency level that the students achieved in TOEFL test. This may be due to the application of compensation during doing the test .The compensation strategies help the students making up for missing knowledge (e.g., guessing from the context in listening and reading; using synonyms). In doing test with limited time and a number of questions such as TOEFL, making up for missing knowledge such as guessing from the context and the using of synonym can become a clue to answer the question.

\section{CONCLUSION}

This research concluded that based on the result of language learning strategies employed by English department students from three majors of study program, the high frequently used strategies were metacognitive strategies and social strategies. Then, it was followed by medium frequently used strategies. Those were cognitive strategies, memory strategies, affective strategies, and compensation strategies. This leads to conclude that the English department students in UNM were high to medium category users of language learning strategies. Based on the data analysis of the total sample from three majors of study program in English department, the mean score of TOEFL $(M=445.81)$ showed that English department students' proficiency level was in the waystage level with the range score 337-459.

There was correlation between students' language learning strategies and their proficiency level. The data analysis showed that the value of $F$ count $=2.2^{9}$ was greater than Ftable $=2.23$ (Fcount> Ftable), or $p=0.45$ was lower than $\alpha=0.05(p<\alpha)$. This result 
indicated that the null hypothesis ( $\mathrm{H} 0$ ) was rejected. This leads to conclude that there was correlation between language learning strategies and proficiency level.

\section{REFERENCES}

Abbot, B. 2002. Human memory. Fort Wayne: Indiana University-Purdue University at Fort Wayne, Psychology Department. Retrieved August $18^{\text {th }}$, 2014, from http://users.ipfw.edu/abbot/120/LongTermMemory.html.

Atkinson, R., \& Shiffrin, R. 1968. Human Memory. A proposed System and Its Control Processes. In K. Spence \& J. Spence (Eds.), The Psychology of Learning and Motivation. Princeton, NJ: Van Nostrand.

Bednar, A.K., Cunningham, D., Duffy, T.M., \& Perry, J.D. 1991. Theory into practice: How do we link? In G.J. Anglin (Ed.), Instructional technology: Past, present, and future. Englewood, CO: Libraries Unlimited.

Bigge, M., \& Shermis, S. (1994). Learning Theories for Teachers, $\left(6^{\text {th }}\right.$ ed). Boston, MA: Pearson.

Bower, G.H., \& Hilgard, E.R. 1981. Theories of Learning (5th ed.). Englewood Cliffs, NJ: Prentice-Hall.

Brown, H. D. (2007). Principle of Language Learning and Teaching, fifth edition. New York: Cambridge University Press

Chamot, A. U. (2004). Issues in Language Learning Strategy Research and Teaching. Electronic Journal of Foreign Language Teaching, 1, 14-26.

Chang, Ching-Yi \& Liu, Shu-Chen \& Lee, Yi-Nan. 2007. A Study of Language Learning Strategies Used by College EFL Learners in Taiwan. (Online, accessed on August 28, 2013. Retrieved from www.mdu.edu.tw/ ged/other\%20download/bulletin/2007 0319/11.pdf.(

Chi, K. and Tam, H. 2013. A Study on Language Learning Strategies (LLSs) of University Students in Hong Kong. Taiwan Journal of Linguistics, Vol. 11. 2, $1-42,2013$.

Creswell, J. W. 2008. Educational Research: Planning, Conducting, and Evaluating Quantitative and Qualitative Research. $3^{\text {rd }}$ Edition. New Jersey: Pearson Merrill Prentice Hall.

Davis, D., \& Sorrell, J. 1995. Mastery Learning in Public Schools. Retrieved July 27, 2014, from http://teach.valdosta.edu/whuitt/files/mastlear.html.

Educational Testing Services. TOEFL ITP Assesment. Available online at http://ets.org. 
Ertmer, P. A. and Newby, T. J. 1993. Behaviorism, Cognitivism, Constructivism: Comparing Critical Features From an Instructional Design Perspective. Journal of Performance Quartely.

Farhady, H. 2010. Measures of Language Proficiency from the Learner's Perspective. University for Teacher Education, Tehran, Iran.

Furwana, D. 2012. Learning Strategies of Sixth Semester Students of English Department of Tarbiyah Faculty at UIN Alauddin Makassar Graduate Program. Makassar: Unpublished Thesis PPs-UNM.

Gagne, R. (1988). Mastery Learning and Instructional Design (chap.4). Retrieved October 25, 2014, from http://www.ibstpi.org/Products/pdf/chapter_4.pdf.

Gavriilidou, Z. and Psaltou-Joycey, A. 2009. Language Learning Strategies: An Overview. JAL, 25 (2009), 11-25. Online, accessed on August 31, 2013. Retrieved from: 01-GAVRIIL-PSALTOU: synmorphose.compulaw.gr/.../3language-learning-strategies-an-overvie...

Gay, et al. 2006. Educational Research. New Jersey: Pearson Prentice Hall.

Gild. 2010. AFT Education Policy Forum. A Union of Professional.

Green, J. M., and Oxford, R. 1995. A Closer Look at Learning Strategies, L2 Proficiency, and Gender. TESOL Quarterly, 29(2), (pp. 261-297).

Griffiths, C. 2003. Language Learning Strategy Use and Proficiency. Auckland: Department of Education, University of Auckland.

Gropper, G.L. 1987. A lesson based on a Behavioral Approach to Instructional Design. In C.M. Reigeluth (Ed.), Instructional Theories in Action (pp. 45-112). Hillsdale, NJ: Lawrence Erlbaum Associates.

Jabu, B. 2008. English Language Testing. Makassar: Badan Penerbit UNM.

Jonassen, D.H. 1991. Evaluating Constructivistic Learning. Educational Technology, 31(9), 28-33.

Ling-Wu, Y. 2008. Language Learning Strategies Used by Students at Different Proficiency Levels. The Asian EFL Journal Quarterly, December 2008Volume 10 , Issue 4.

Lutz, S., \& Huitt, W. 2003. Information Processing and Memory: Theory and Applications. Educational Psychology Interactive. Valdosta, GA: Valdosta State University. Retrieved [August 18 ${ }^{\text {th }}$ 2014], from http://www.edpsycinteractive.org/papers/info proc.pdf. 
Maulina. 2013. The Correlation among Gender, Language Learning Strategies, and English Achievement of English Department Students of Tarbiyah Faculty at UIN Alauddin Makassar. Makassar: Unpublished Thesis PPs-UNM.

McGonical, K. (2005). Teaching for Transformation from Learning Theory to Teaching Strategies. Retrieved September 20, 2014, from http://www.Stanford.edu/dept/CTL/ egi-bin/does/newsletter/transformation.pdf.

Mohammadi, M. 2009. On the Relationship between Learning Strategies and EFL Learners' Level of Proficiency. Journal of Modern Taught in English Education, Vol. 4, no. 3, 103-116.

Nur Biati. 2014. The Correlation between Motivation, English Achievement and Learning Strategies of the Second Year Students of SMA 12 Makassar. Makassar: Unpublished Thesis PPs-UNM.

O’Malley, J. M. and Chamot, A. U. 1990. Learning Strategies in Second Language Acquisition. Cambridge: Cambridge University Press.

Oxford. R. L. 1990. Language Learning Strategies: What Every Teacher Should Know. Boston: Heinle \& Heinle.

Pannak, O. and Chiramanee, T. 2011. Language Learning Strategies Used by First Year Students at Thaksin University, Songkhla Campus, Thailand. The $3^{\text {rd }}$ International Conference on Humanities and Social Sciences, April 2, 2011.

Pham, H. (2011). Theory-Based Instructional Models Applied in Classroom Contexts. Literacy Information and Computer Education Journal (LICE), volume2, 2011.

Radwan, A. A. 2011. Effects of L2 Proficiency and Gender on Choice of Language Learning Strategies by University Students Majoring in English. The Asian EFL Journal Quarterly, March 2011, Vol. 13, Issue 1.

Riduwan. 2013. Metode dan Teknik Menyusun Proposal Penelitian. Bandung: Penerbit Alfabeta.

Rubin, J. 1987. Learner Strategies: Theoretical Assumptions, Research History and Typology. In A. L. Wenden and J. Rubin (Eds.), Learner Strategies in Language Learning, 15-30. London: Prentice-Hall International (UK) Ltd.

Salahshour et al., 2013. The Relationship between Language Learning Strategy Use, Language Proficiency Level and Learner Gender. Procedia-Social and Behavioral Sciences, 70 (2013), 634-643. Available online at www.sciencedirect.com. 
Schunk, D.H. 1991. Learning Theories: An Educational Perspective. New York: Macmillan.

Sugiyono. 2007. Metode Penelitian Kuantitatif dan Kualitatif. Bandung: CV. Alfabeta.

Trihendradi, C. 2012. Step by Step SPSS 20: Analisis Data Statistik. Yogyakarta: Penerbit Andi.

Weda, Sukardi. 2005. English Learning Strategies Employed by Senior Secondary School Students. Makassar: Unpublished Dissertation PPs-UNHAS.

Weda, Sukardi. 2007. English Learning Strategies. Makassar: Lembaga Pusat Pengembangan Masyarakat Marginal (LPPMM).

Wenden, A. L. 1987. Conceptual Background and Utility. In A. L. Wenden and J.Rubin (Eds.), Learner Strategies in Language Learning, 3-13. London: Prentice-Hall International (UK) Ltd.

Yilmaz, C. 2010. The Relationship between Language Learning Strategies, Gender, Proficiency and Self-Efficacy Beliefs: A Study of ELT Learners in Turkey. Journal of Procedia Social and Behavioral Sciences, 2 (2010), 682-687. Available online at www.sciencedirect.com. 